Volume 9. Nomor 2. Desember 2014
Pandecta
http://journal.unnes.ac.id/nju/index.php/pandecta

\title{
Pendekatan Ekoregion Dalam Sistem Hukum Pengelolaan Sumber Daya Air Sungai di Era Otonomi Daerah
}

\author{
Nita Triana ${ }^{凶}$ \\ Jurusan Syariah IAIN Purwokerto
}

\begin{tabular}{l} 
Info Artikel \\
\hline Sejarah Artikel: \\
Diterima Oktober 2014 \\
Disetujui November 2014 \\
Dipublikasikan Desember 2014 \\
\hline Keywords: \\
Regional Regulation; \\
Autonomous Regions; \\
Resources river water; \\
Ecoregion \\
\hline
\end{tabular}

\begin{abstract}
Abstrak
Hak atas lingkungan yang baik dan sehat dijamin oleh Pancasila dan UUD 1945 yang berimplikasi terhadap perlunya kebijakan, rencana dan/atau program mengenai hak atas lingkungan tersebut diatur dalam perundang-undangan, baik di tingkat nasional maupun daerah. Dalam konteks otonomi daerah hak atas lingkungan tersebut termasuk dalam kelompok bidang urusan wajib pemerintahan. Tulisan ini bertujuan untuk menganalisis dampak pengaturan hak atas lingkungan hidup dalam bidang sumber daya air. Hasil penelitian ini menunjukkan bahwa dampak pengaturan hak atas lingkungan hidup dalam sistem hukum pengelolaan sumber daya air sungai tidak terintegrasi dengan daerah lain, sehingga kebijakan pemerintah daerah lebih ditujukan untuk peningkatan pendapatan daerah masing-masing. Kondisi ini mengakibatkan terjadinya perusakan sumber daya air sungai di bagian hulu dan hilir dan tidak optimalnya pemanfaatan air sungai. Berdasarkan hal tersebut dibutuhkan sistem hukum pengelolaan sumber daya air dengan pendekatan ekoregion, dimana batas darat dan perairan tidak ditentukan oleh batas secara politik, akan tetapi oleh batas geografis dari komunitas manusia dan sistem lingkungan.
\end{abstract}

\begin{abstract}
The right to a good and healthy environment is guaranteed by Pancasila and the 1945 Constitution which has implications on the need for policies, plans and / or programs on environmental rights are set out in legislation, both at national and local levels. In the context of regional autonomy, rights to the environment including the obligatory group of government issues. This paper aims to analyze the impact of regulation on environmental rights in the field of water resources. The results of this study indicate that the impact of regulation on environmental rights in the legal system of management of water resources of the river is not integrated with other areas, so that local policy is intended to increase local revenues respectively. These conditions resulted in the destruction of the water resources of the river upstream and downstream and is not optimal utilization of river water. Under the terms of the legal system needs water resources management with ecoregion approach, where land and water boundaries are not defined by political boundaries, but by the geographical boundaries of the human community and environmental systems.
\end{abstract}




\section{Pendahuluan}

Indonesia sebagai Negara kepulauan memiliki banyak aliran sungai, sebagian diantaranya adalah sungai-sungai besar seperti Mahakam, Kapuas, Barito, Brantas, Serayu, Ciliwung dan lain-lain yang memiliki potensi sumber daya air yang besar. Banyaknya sungai di Indoensia ini merupakan potensi tersendiri untuk bisa mensejahterakan rakyat banyak, terkait dengan penyediaan air bersih dan air minum. Keberadaan sungai-sungai ini merupakan suatu potensi besar yang dikaruniakan Tuhan untuk kemudian dimanfaatkan untuk kesejahteraan manusia. Air sungai memiliki keuntungan tersendiri dibanding dengan sumber air permukaan lain dari segi ketersediaan dan kemudahan pengambilannya. Keuntungan yang kedua adalah karena letaknya yang di permukaan membuatnya mudah untuk diambil dan diolah. Teknik pengolahannya relative sederhana sehingga tidak terlalu memerlukan biaya instalasi pengolahan yang besar. Dengan kemudahan inilah maka air sungai memiliki potensial yang besar untuk bisa dimanfaatkan di Indonesia.

Masalah yang timbul pada pengelolaan air sungai adalah air sungai ketersediannya tunduk pada siklus alami yang disebut siklus hidrologi. Pada saat musim kemarau sering terjadi krisis air. Di Indonesia krisis air telah sampai pada titik mencemaskan baik di kota besar maupun di desa, sementara di musim penghujan sumber daya air sungai meluap dan menjadi bencana banjir. Masalah lain yang cukup parah adalah kondisi air sungai yang tercemar limbah cair dan padat (sampah) di berbagai tempat. Pencemaran dan Perusakan sumber daya air sungai merupakan permasalahan serius yang dihadapi oleh pemerintah dan masyarakat dalam mengatur pengeloaan sumber daya air (Efendi, 2008: 93).

Krisis air telah menyebabkan perubahan yang cukup besar pada nilai air, yang tadinya air lebih berfungsi sosial, saat ini air telah berubah menjadi berfungsi ekonomi. Air sungai sebagai salah satu sumber potensial kebutuhan akan air menjadi hal yang sangat penting untuk diperjuangkan keberadaannya oleh satu daerah tertentu. Masalahnya tim- bul ketika aliran air sungai tersebut melewati beberapa daerah. Hal hal tersebut diatas menimbulkan konflik antar daerah dan antar berbagai pihak yang terkait dengan sumber daya air.

Penelitian yang dilakukan oleh Sam'un Jaja Raharja (2009: 86) dari segi administrasi negara menunjukan bahwa sifat sungai yang mengalir dan melintasi batas wilayah administratif dan bahkan negara, banyak pihak yang berkepentingan dan atas nama "hak" yang dimilikinya, terjadi eksploitasi sesuai dengan tujuan masing-masing yang spesifik. Keadaan ini berpotensi memunculkan kompetisi dan konflik, baik yang bersifat horisontal maupun vertikal. Konflik yang dimaksud antara lain konflik kuantitas berkaitan dengan kelangkaan, konflik kualitas karena pencemaran dan kerusakan lingkungan, konflik organisasional, karena pengelolaan yang fragmentaris dan sektoral atau kewilayahan administratif, konflik nilai berkaitan dengan pandangan penguasaan dan pemanfaatan sumber air sebagai barang publik atau privat dan komoditas ekonomi global. Ironisnya dan sekaligus juga paradoks, yaitu manakala terjadi hal-hal negatif pada aliran sungai, seperti pencemaran, banjir, dan kekeringan, masing-masing pihak cenderung saling menyalahkan.

Demikian juga penelitian dari I Gusti Ayu Ketut Rachmi Handayani dan Lintje Anna Marpaung (2013) menunjukkan bahwa ketentuan Pasal 11 ayat (2) Undang Undang Nomor 32 Tahun 2004 jo Undang Undang Nomor 12 Tahun 2008 Tentang Pemerintahan Daerah, membuka peluang terjadinya disintegrasi bagi pengelolaan lingkungan hidup. Terfokusnya Otonomi Daerah pada tingkat Kota dan Kabupaten yang ditinjau baik dari segi kewengannya maupun dari segi perimbangan keuangan yang diterimanya, maka daerah provinsi semakin jauh dari adanya kewajiban untuk mewujudkan dan melaksanakan kebijakan dalam bidang hukum lingkungan.

Disamping itu, Otonomi Daerah yang banyak memberikan kewenangan kepada daerah Kota dan Kabupaten dalam mengeluarkan kebijakan di bidang lingkungannya akan mengakibatkan timbulnya kebijakan- 
kebijakan lingkungan hidup yang saling tumpang tindih antara daerah yang satu dengan daerah yang lainnya, yang bisa mengakibatkan kerugian terhadap pelaksanaan kebijakan penegakan hukum lingkungan itu sendiri.

Tulisan ini akan menganalisis lebih kauh lagi hasil penelitian terdahulu tersebut dengan memfokuskan pada urgensi pendekatan ekoregion dalam sistem hukum pengelolaan sumber daya air sungai untuk mewujudkan pembangunan berkelanjutan.

\section{Metode Penelitian}

Penelitian ini merupakan penelitian hukum non doktrinal dengan pendekatan socio-legal research, (Irianto, 2009a: 37; Irianto, 2009b:177; Wignjosoebroto, 2009;120). Melalui pendekatan ini pengkajian dilakukan dengan mendeskripsikan substansi normanorma hukum pengelolaan sumber daya air sungai yaitu Undang-Undang Nomor 7 Tahun 2004 tentang Sumber Daya Air, PP Nomor 37 Tahun 2012 Tentang Daerah Aliran Sungai (DAS), Peraturan Pemerintah (PP) Nomor 38 Tahun 2011 tentang Sungai, Undang-Undang Nomor 32 tahun 2004 jo Undang-Undang Nomor 12 Tahun 2008 Tentang Pemerintahan Daerah, Undang-Undang Nomor $32 \mathrm{Ta}-$ hun 2009 Tentang Perlindungan dan Pengelolaan Lingkungan Hidup dan realitas sosial yang ada dalam pengelolaan sumber daya air sungai, serta keterkaitan antara keduanya. Secara lebih konkrit metode yang digunakan adalah metode kualitatif. Paradigma yang digunakan adalah paradigma kritis atau critical legal theory (Giddens, 2008:138). Penelitian ini mengkritisi penyelenggaraan peraturan sumber daya air sungai dengan jalan yang lebih demokratis, yaitu dengan melibatkan berbagai pihak di dalam birokrasi pemerintahan daerah dan masyarakat sebagai kesatuan yang integratif holistik. Penelitian ini menggunakan Konsep pemikiran Deep Ecology dari Fritjop Capra, Teori Sistem Hukum dari Friedman, Teori Birokrasi dan Post-Birokrasi dari Nonet and Selznick, dan Teori Keadilan Ekologi dari Nicholas Low and Brendan Gleeson, serta konsep Negara Ekokrasi.

\section{Hasil dan Pembahasan}

\section{a. Pengelolaan Sumber Daya air Sun- gai di Era Otonomi Daerah}

Pengelolaan sumber daya air sungai tidak terlepas dari berbagai permasalahan, antara lain masalah penurunan sumberdaya alamiah, polusi dari berbagai sumber, serta konflik penggunaan lahan di sekitar Daerah Aliran Sungai (DAS). Saat ini kondisi DAS di sebagian besar daerah di Indonesia cenderung menurun. DAS memikul beban yang sangat berat dengan meningkatnya kepadatan penduduk di sekitar DAS dan meningkatnya pemanfaatan atau eksploitasi sumber daya alam secara intensif sehingga kondisi DAS mengalami degradasi (Asdak, 1999: 47).

Hasil pemantauan kualitas air melalui pengukuran Indeks Kualitas Air pada 13 sungai dan 40 situ yang ada di wilayah DKI Jakarta menunjukkan bahwa 83\% sungai dan $79 \%$ situ berada dalam kategori buruk. Hasil penelitian yang mengacu pada studi Departemen PU ini perlu dicermati mengingat sungai memiliki peran penting sebagai salah satu sumber daya alam pendukung kehidupan manusia. Selain penurunan kualitas air, terjadi pula kecenderungan peningkatan bencana di sekitar DAS, seperti tanah longsor, erosi dan sedimentasi.

Musibah kejadian bencana sekitar DAS yang merupakan gabungan masalah kurangnya pemeliharaan infrastruktur dan dampak negatif dari eksploitasi lingkungan. Halini

terjadi baik di kawasan hulu berupa penebangan hutan maupun di kawasan hilir berupa perubahan lahan irigasi dan persawahan untuk kepentingan ekonomi. Eksploitasi lingkungan yang terjadi antara lain ditunjukkan oleh berkurangnya luas situ akibat adanya pembangunan permukiman, yang mengubah kondisi lingkungan .

Kasus bencana di sekitar DAS terkait dengan pelaksanaan tata ruang yang tidak terkendali, dan kurangnya pemeliharan infrastruktur dengan baik di kawasan hulu. Kasus ini juga menunjukkan pentingnya pengelolaan lingkungan pada wilayah DAS pada tingkat makro. Selain itu, kasus bencana ini juga menunjukkan pengaruh aspek ekonomi yang memicu masyarakat untuk mengeksploitasi 
lingkungan demi memperoleh keuntungan. Hal ini disebabkan karena tidak berjalannya dengan baik kebijakan publik yang dibuat oleh pihak Pemerintah Daerah atau kebijakan pemerintah daerahnya yang belum memiliki keseimbangan antara tiga aspek, yaitu lingkungan, ekonomi dan sosial dan juga kurangnya koordinasi antar daerah hulu-hilir.

Masalah tentang pengelolaan sumber daya air sungai antara daerah hulu dan hilir adalah permasalahan di era desentralisasi dan otonomi daerah. Era otonomi daerah telah merubah berbagai kewenangan dibidang lingkungan hidup yang semakin terbatas di tingkat pemerintaha pusat dan propinsi akan tetapi menjadi lebih besar di tingkat Kabupaten /Kota. Undang-Undang Nomor 32 tahun 2004 jo Undang-Undang Nomor 12 Tahun 2008 tentang Pemerintahan Daerah yang selanjutnya disingkat UUPD pada dasarnya meletakan kewenangan Pemerintahan Daerah Kabupaten/Kota.

Berdasarkan Pasal 11 ayat (2), UUPD menjelaskan kewenangan Pemerintahan Daerah dilaksanakan secara luas, utuh dan bulat meliputi tahap perencanaan, pengawasan, pengendalian dan evaluasi bidang Pemerintahan yang wajib dilaksanakan Kabupaten/ Kota. Dikaitkan dengan pengelolaan sumber daya air sungai, maka pengelolaan ini termasuk pengelolaan yang harus dilakukan oleh pemerintahan daerah Kabupaten/Kota. Hal ini dapat dikaji melalui isi ketentuan Psl 11 ayat 2 UUPD, yang menyebutkan tentang bidang pemerintahan yang wajib dilaksanakan daerah Kabupaten/Kota salah satunya adalah Lingkungan Hidup.

Disintegrasi Sumber Daya Alam Nasional ini adalah hasil dari inkonsistensi aturan otonomi daerah dengan aturan perundangundangan yang menyangkut masalah lingkungan hidup. Ketentuan pasal 11 ayat 2 UUPD yang memasukan bidang lingkungan hidup sebagai salah satu bidang pemerintahan yang wajib dilaksanakan oleh daerah Kota/Kabupaten telah melemahkan pasal 9 Undang-Undang tentang Perlindungan dan Pengelolaan Lingkungan Hidup (UUPPLH) (yang mengamanatkan tentang pengelolaan laingkungan hidup berbasis ekoregion) menjadi terpecah dengan adanya pemilahan ke- wenangan pengelolaan Lingkungan Hidup yang terungkap dalam UUPD (Handayani dan Marpaung, 2013).

Implikasi dari ketentuan UUPD ini adalah masing-masing daerah lebih condong mempergunakan paradigma pembangunan yang mementingkan aspek-aspek ekonomi dan politik dalam rangka mendapatkan pendapatan asli daerah (PAD) setinggi-tingginya, dengan menyederhanakan permasalahan lingkungan. Berdasarkan paradigma pembangunan tersebut, maka pengelolaan lingkungan yang dilakukan dibatasi dalam lingkup wilayah administrasi. Ruang lingkup dengan hanya memperhatikan batas administrasi pemerintahan, terlalu sempit untuk menjamin kehidupan populasi dan pengendalian ancaman kepunahan spesies serta pemeliharaan proses-proses ekologi yang mendukungnya. Akibatnya banyak Perda-Perda yang berkaitan dengan pengelolaan sumber daya alam , serta struktur kepengurusannya dilakukan oleh masing-masing daerah.

Otonomi daerah yang bermakna kemandirian, pada tataran praksisnya dalam beberapa hal masih secara rancu dimaknai sebagai keharusan untuk melakukannya sendirian. Wawasan pengelolaan sumber daya alam seringkali dimaknai hanya seluas administratif pemerintah daerah semata, akibatnya yang muncul adalah ego daerah semata. Praktek pengelolaan sumber daya alam yang berangkat dari perspektif seperti ini banyak melahirkan paradoks dalam pengelolaan sumber daya alam di era otonomi daerah seperti konflik horisontal dan konflik vertikal.

\section{b. Pengaturan Lingkungan Hidup dili- hat dari Teori Bekerjanya Hukum}

Konstitusi (UUD 1945) sebagai hukum tertinggi yang menjadi sumber hukum formil maupun materiil telah diamandemen sebanyak 4 (empat) kali. Sejatinya perubahan tersebut dimaksudkan untuk merespon perkembangan dan dinamika zaman. Salah satu aspek penting dari amandemen UUD 1945 adalah lahirnya suatu gagasan tentang pentingnya lingkungan hidup (ecocracy) yang sehat sebagai bagian dari hak asasi manusia. ini kemudian dinormakan dalam UUD 1945. 
Secara jelas dalam Pasal $28 \mathrm{H}$ ayat (1) " Setiap orang berhak hidup sejahtera lahir dan batin, bertempat tinggal, dan mendapatkan lingkungan hidup yang baik dan sehat serta berhak memperoleh pelayanan kesehatan" (Asshiddiqie, 2010:117).

Adanya ketentuan hak asasi bagi setiap orang sebagaimana dimaksud dalam Pasal $28 \mathrm{H}$ ayat (1), mengharuskan Negara untuk menjamin terpenuhinya hak tersebut. Disisi lain kita sebagai warga Negara mempunyai kewajiban untuk menghormati hak asasi orang lain atas lingkungan hidup yang baik dan sehat. Disamping diatur dalam pasal $28 \mathrm{H}$ ayat 1 , pengelolaan lingkungan hidup yang suitable juga diatur dalam pasal 33 ayat 3 UUD 1945, "Bumi dan air dan kekayaan alam yang terkandung di dalamnya dikuasai oleh Negara dan dipergunakan untuk sebesar-besarnya kemakmuran rakyat".

Pengaturan lingkungan hidup yang pada awalnya dimuat dalam UU kemudian "diangkat" dalam UUD merupakan suatu upaya serius yang dilakukan oleh pemerintah untuk menjamin keberlangsungan fungsi lingkungan hidup agar dapat dinikmati oleh generasi yang akan datang. Konsekuensi dari diaturnya lingkungan hidup ke dalam UUD 1945 adalah kebijakan, rencana dan/atau program yang dilaksanakan oleh pemerintah harus melihat aspek keberlanjutan lingkungan hidup. Dengan demikian kebijakan, rencana dan/atau program yang tertuang dalam bentuk UU, Perpu, PP, Perda tidak boleh bertentangan dengan ketentuan konstitusional yang pro-lingkungan.

Saat ini Undang Undang yang berkaitan mengatur tentang sumber daya air sungai adalah: Undang-Undang Nomor 7 Tahun 2004 tentang Sumber Daya Air sebagai produk legislatif masa reformasi, telah menggantikan Undang-Undang Nomor 11 Tahun 1974 tentang Pengairan. Undang-Undang Nomor 7 Tahun 2004 tentang SDA mempunyai kelebihan jika dibandingkan dengan UU Pengairan. Kelebihan tersebut yaitu bahwa UU SDA mengatur secara terperinci mengenai air yang dikaitkan dengan konsep 3 pilar pengelolaan sumber daya air. Ketiga pilar pengeloaan tersebut adalah fungsi sosial, lingkungan hidup, dan ekonomi.Fungsi sosial berarti ke- pentingan umum lebih diutamakan daripada kepentingan individu. Pilar lingkungan hidup berarti bahwa sumber daya air menjadi bagian dari ekosistem sekaligus sebagai tempat hidup flora dan fauna. Pilar ekonomi berarti bahwa sumber daya air dapat didayagunakan untuk menunjang kegiatan usaha yang diselenggarakan dan diwujudkan secara selaras (Budiman,1999:194).

Peraturan Pemerintah (PP) Nomor 38 Tahun 2011 tentang Sungai merupakan peraturan perundang-undangan yang mengatur khusus tentang sungai. Pasal 18 ayat 1 PP Nomor 38 Tahun 2011 tentang Sungai menegaskan, Pengelolaan sungai meliputi: a.konservasi sungai; b.pengembangan sungai; dan c. pengendalian daya rusak air sungai. Mengenai kewenangannya untuk melakukan konservasi, pengembangan dan pengendalian ini terdapat dalam Pasal 19 ayat 1.

Pasal 19 ayat 1 , menyebutkan Pengelolaan sungai sebagaimana dimaksud dalam Pasal 18 dilakukan oleh: a. Menteri, untuk sungai pada wilayah sungai lintas provinsi, wilayah sungai lintas negara, dan wilayah sungai strategis nasional; b. Gubernur, untuk sungai pada wilayah sungai lintas kabupaten/ kota; dan c. Bupati/Walikota, untuk sungai pada wilayah sungai dalam satu kabupaten/ kota. Selanjutnya Pasal 19 ayat 2: Pengelolaan sungai sebagaimana dimaksud pada ayat (1) dilakukan dengan melibatkan instansi teknis dan unsur masyarakat terkait. Dan ayat (3).Pengelolaan sungai dilaksanakan berdasarkan norma, standar, pedoman, dan kriteria yang ditetapkan oleh Menteri.

Selanjutnya Pemerintah mengeluarkan lagi Peraturan pemerintah yang mengatur tentang Daerah Aliran Sungai (DAS) yaitu PP No.37 Tahun 2012 ayat (2) menyebutkan tentang Penyusunan Klasifikasi DAS dilakukan untuk menentukan: a. DAS yang dipulihkan; dan b. DAS yang dipertahankan, daya dukungnya.(3).Penentuan Klasifikasi DAS sebagaimana dimaksud pada ayat (2) dilakukan berdasarkan kriteria: a. kondisi lahan; b. kualitas, kuantitas dan kontinuitas air; c. sosial ekonomi; d. investasi bangunan air; dan e. pemanfaatan ruang wilayah.

Selanjutnya Pasal 22 ayat 1 berdasar- 
kan penetapan klasifikasi DAS sebagaimana dimaksud dalam Pasal 12, dilakukan penyusunan Rencana Pengelolaan DAS. Ayat (2) Penyusunan RencanaPengelolaan DAS dilakukan oleh:a.Menteri untuk DAS lintas negara dan DAS lintas Provinsi; b. Gubernur sesuai kewenangannya untuk DAS dalam provinsi dan/atau lintas kabupaten/kota; c. Bupati/Walikota sesuai kewenangannya untuk DAS dalam kabupaten/kota. Dalam Ayat 3 diterangkan: dalam menyusun Rencana Pengelolaan DAS sebagaimana dimaksud pada ayat (2) Menteri, gubernur, bupati/walikota sesuai kewenangannya dapat membentuk tim dengan melibatkan Instansi Terkait

Namun ditingkat implementasi pelaksanaan kewenangan kelembagaan ini menghadapi masalah. Kendala otonomi pengelolaan sumber daya air sungai yang berkaitan dengan dengan aspek kelembagaan adalah masalah koordinasi pemafaatan sumber daya air yang bersifat ganda (multi purpose), (Sulastriyono, 2008:65). Penanganannya perlu koordinasi. Koordinasi tersebut dapat bersifat vertikal yaitu antara instansi di pusat dan di daerah dan koordinasi secara horisontal antar instansi seperti Departeman Dalam Negeri (DEPDAGRI), Departemen Pekerjaan Umum (DPU), Badan Lingkungan Hidup, Departemen Perhubungan (DEPHUB), Departemen Pertambangan dan Energi, Departemen Perindustrian, Departemen Kesehatan, Departemen Kehutanan dan sebagainya. Dalam pelaksanaan koordinasi secara vertikal dirasakan lebih mudah dilaksanakan karena ada perbedaan kedudukan.

Koordinasi secara horisontal masih dirasakan kurang, untuk itu dalam rangka pengaturan pengelolaan sumber daya air secara holistik dan terpadu perlu ada solusi agar koordinasi secara horisontal dapat dilaksanakan dengan baik Kurangnya pelaksanaan koordinasi secara horisontal disebabkan batas kewenangan dan urusan satu instansi dengan instansi lainnya umumnya tidak diatur secara jelas, sehingga tidak ada kepastian ruang lingkup dan batas kewenangan masing masing sektor.

Permasalahan lainnya adalah kurangnya koordinasi antar wilayah antar daerah. Badan Perencanaan dan Pembangunan Da- erah (Bappeda), Dinas Tata Ruang, Badan Lingkungan Hidup, Dinas Perumahan dan Bangunan, Dinas Pariwisata di daerah yang satu kurang beroordinasi dengan daerah lainnya, hal ini mengakibatkan berbagai kebijakan dan peraturan perundang-undangan yang ada sekarang bersifat sektoral atau regional/lokal dan kurang memperhatikan permasalahan lintas sektoral. konsep pengaturan pengelolaan sumber daya air yang bersifat holistik dan terpadu dengan berbasis kearifan lokal diperlukan sebagai salah satu alternatif dalam melaksanakan pengelolaan sumber daya air (Akib, 2011:67).

Berdasarkan hal tersebut diatas, maka kembali kepada amanat dari konstitusi, permasalahan yang berkaitan dengan pengelolaan sumber daya air sungai harus segera diperbaiki. Sistem hukum yang selama ini ada di daerah-daerah perlu dibangun kembali untuk mengurangi salah kelola yang berakibat timbulnya berbagai bencana dan kerugian yang amat besar karena tidak maximalnya hasil yang didapatkan dari sumber daya air sungai tersebut. Untuk itu perlu diperhatikan bekerjanya sistem hukum dalam pengelolaan sumber daya air sungai.

Proses bekerjanya sistem hukum, yang menurut L. Friedman terdiri atas tiga aspek (Friedman,1975). Pertama, Struktur Hukum, yaitu bagian-bagian yang bergerak di dalam suatu mekanisme yang merupakan kelembagaan yang diciptakan oleh sistem hukum dan mempunyai fungsi untuk mendukung bekerjanya sistem hukum (seperti lembagalembaga hukum dan hubungan atau pembagian kekuasaan antar lembaga hukum). Kedua, Substansi Hukum, yaitu hasil aktual yang diterbitkan oleh sistem hukum yang berupa norma-norma hukum, baik peraturanperaturan, keputusan-keputusan yang digunakan oleh para penegak hukum maupun oleh mereka yang diatur hukum. Keempat, Kultur atau Budaya hukum, Friedman mengatakan bahwa substansi dan struktur merupakan komponen nyata dari sistem hukum, akan tetapi hal itu merupakan cetak biru saja/ blueprint desain hukum dan belum mendeskripsikan yang sebenarnya dari cara kerja mesin hukum. Dengan demikian budaya hukum merupakan ide-ide, sikap, harapan 
dan pendapat tentang hukum sebagai keseluruhan faktor yang menentukan bagaimana sistem hukum memperoleh tempatnya yang logis.

Menurut Friedman, kultur hukum adalah suasana pikiran sosial dan kekuatan sosial yang menentukan bagaimana hukum digunakan, dihindari atau disalahgunakan. Tanpa kultur hukum, maka sistem hukum itu sendiri tidak berdaya, seperti "ikan mati yang terkapar di keranjang, dan bukan seperti ikan hidup yang berenang di laut". Komponen kultural yaitu terdiri dari nilai-nilai dan sikap-sikap yang mempengaruhi bekerjanya hukum, atau yang menurut Friedman disebut sebagai kultur hukum. Kultur hukum inilah yang berfungsi sebagai jembatan yang menghubungkan antara peraturan hukum dengan tingkah laku hukum seluruh warga masyarakat.

Sistem hukum terdiri dari tiga bagian itu bisa diibaratkan sebagai berikut: 1). Struktur hukum diibaratkan sebagai mesin; 2). Substansi hukum adalah apa yang dikerjakan dan dihasilkan oleh mesin itu; 3). Kultur hukum adalah apa saja atau siapa saja yang memutuskan untuk menghidupkan dan mematikan mesin itu, serta memutuskan bagaimana mesin itu digunakan. (Rahardjo, 2009: 69).

\section{c. Ekoregion Approach dalam Sistem Hukum Pengelolaan Sumber Daya Air}

Pengelolaan Sumber Daya Air Sungai diatur dalam Peraturan Pemerintah Nomor 37 Tahun 2012 tentang Pengelolaan Daerah Aliran Sungai. Pengelolaan DAS adalah pengelolaan sumber daya alam yang dapat diperbaharui, yaitu tumbuhan, tanah dan air, agar dapat memberikan manfaat yang maksimal dan berkesinambungan. Pengelolaan DAS merupakan upaya manusia dalam mengendalikan hubungan timbal balik antara sumberdaya alam dengan manusia dan segala aktifitasnya didalam DAS. Adapun tujuan Pengelolaan DAS adalah: mewujudkan kondisi tata air DAS yang optimal meliputi kuantitas, kualitas dan distribusi menurut ruang dan waktu, mewujudkan kondisi lahan yang produktif secara berkelanjutan, mewujudkan kesejahteraan masyarakat yang

\section{berkeadilan}

Untuk mencapai tujuan pengelolaan DAS, maka ruang lingkup pengelolaan DAS harus meliputi: penatagunaan lahan pengelolaan Sumber Daya Air, pengelolaan lahan dan vegetasi, pengelolaan dan pengembangan Sumber Daya Buatan, pemberdayaan masyarakat dan pengembangan kelembagaan. Dengan pengelolaan DAS yang benar diharapkan tercapainya kondisi hidrologis yang optimal, meningkatnya produktifitas lahan yang diikuti oleh perbaikan kesejahteraan masyarakat, terbentuknya kelembagaan masyarakat yang tangguh dan muncul dari bawah sesuai dengan kondisi sosial budaya setempat, serta terwujudnya pembangunan yang berkelanjutan, berwawasan lingkungan dan berkeadilan.

Beberapa prinsip dasar dalam pengelolaan DAS adalah: DAS sebagai suatu kesatuan ekosistem dari hulu sampai hilir, satu Perencanaan dan satu pengelolaan multipihak, koordinatif, menyeluruh dan berkelanjutan, adaptif dan sesuai dengan karakteristik DAS, pembagian beban biaya dan manfaat antar multipihak secara adil dan akuntabel. Prinsip pengelolaan Daerah Aliran Sungai ini adalah prinsip pengelolaan lingkungan dengan pendekatan ekoregion (Sunarti, 2008:91).

Ekoregion adalah batas darat dan perairan dimana batas tersebut tidak ditentukan oleh batas secara politik, akan tetapi oleh batas geografis dari komunitas manusia dan sistem lingkungan. Luas area ini harus cukup besar guna mempertahankan integritas komunitas biologi wilayah tersebut, habitat dan ekosistem untuk menyokong proses-proses ekologi yang penting seperti siklus nutrient dan limbah, migrasi dan aliran arus. Untuk menjaga habitat dari spesies-spesies yang penting dan juga mencakup komunitas manusia yang terlibat di dalam pengelolaan alam, penggunaan dan memahami proses-proses biologi.

Dasar hukum ekoregion ini terdapat dalam Undang-Undang Nomor 32 Tahun 2009 tentang Perlindungan dan Pengelolaan Lingkungan Hidup. UU Nomor 32 Tahun 2009 memandatkan perlu diperkuatnya perencanaan perlindungan dan pengelolaan Lingkungan Hidup (RPPLH). Rencana perlin- 
dungan dan pengelolaan Lingkungan Hidup terdiri dari empat muatan, yaitu: (1) pemanfaatan dan/atau pencadangan sumber daya alam; (2) pemeliharaan dan perlindungan kualitas dan/atau fungsi lingkungan hidup; (3) pengendalian, pemantauan, serta pendayagunaan dan pelestarian sumber daya alam; dan (4) adaptasi dan mitigasi terhadap perubahan iklim. Untuk memperkuat perencanaan perlindungan dan pengelolaan lingkungan hidup tersebut, UU Nomor 32 Tahun 2009 menegaskan bahwa untuk menyusun rencana perlindungan dan pengelolaan lingkungan hidup harus berbasis ekoregion yang mempertimbangkan karakteristik wilayah.

Selanjutnya dalam UU Nomor 32 Tahun 2009 tersebut menerangkan bahwa Ekoregion adalah geografis ekosistem, artinya pola susunan berbagai ekosistem dan proses di antara ekosistem tersebut yang terikat dalam suatu satuan geografis. Penetapan ekoregion menghasilkan batas (boundary) sebagai satuan unit analisis dengan mempertimbangkan ekosistem pada sistem yang lebih besar. Penetapan ekoregion tersebut menjadi dasar dan memiliki peran yang sangat penting dalam melihat keterkaitan, interaksi, interdependensi dan dinamika pemanfaatan berbagai sumberdaya alam antar ekosistem di wilayah ekoregion.

Penyusunan Rencana Perlindungan dan Pengelolaan Lingkungan Hidup atau RPPLH perlu memperhatikan keragaman dan karakteristik fungsi ekologis, kepadatan penduduk, sebaran potensi SDA, kearifan lokal dan aspirasi masyarakat serta perubahan iklim. Analisis berbasis ekoregion yang mempunyai karakteristik tertentu, akan memperkuat dalam mewujudkan pula arah penekanan perbedaan Perencanaan Perlindungan dan Pengelolaan Lingkungan Hidup pada pulau-pulau besar maupun kepulauan yang mempertimbangkan aspek darat dan laut. UU Nomor 32 Tahun 2009 memberi peluang besar untuk mengelola lingkungan hidup dan sumberdaya alam secara lebih efektif. Hal ini akan memperkuat pula perencanaan pembangunan nasional dan wilayah, terlebih secara mandat dalam UU Nomor 32 Tahun 2009 dinyatakan bahwa RPPLH dijadikan dasar dan dimuat dalam Rencana Pemban- gunan Jangka Panjang (RPJP) dan Rencana Pembangunan Jangka Menengah (RPJM).

Secara prinsip, pendekatan ekoregion juga bertujuan untuk memperkuat dan memastikan terjadinya koordinasi horisontal antar wilayah administrasi yang saling bergantung (hulu-hilir) dalam pengelolaan dan perlindungan lingkungan hidup yang mengandung persoalan pemanfaatan, pencadangan sumber daya alam maupun permasalahan lingkungan hidup. Selain itu, pendekatan ekoregion mempunyai tujuan agar secara fungsional dapat menghasilkan Perencanaan Perlindungan dan Pengelolaan Lingkungan Hidup, pemantauan dan evaluasinya secara bersama antar sektor dan antar daerah yang saling bergantung, meskipun secara kegiatan operasional pembangunan tetap dijalankan sendiri-sendiri oleh sektor/dinas dan wilayah administrasi sesuai kewenangannya masingmasing. Dasar pendekatan ini juga akan mewujudkan penguatan kapasitas dan kapabilitas lembaga (sektor/dinas) yang disesuaikan dengan karakteristik dan daya dukung sumber daya alam yang sedang dan akan dimanfaatkan.

Pendekatan ekoregion juga terdapat dalam Kajian Lingkungan Hidup Strategis atau KLHS. atau yang juga dikenal sebagai Strategic Environmental Assessment (SEA). Konsep KLHS telah di implementasikan secara efektif di negara-negara Eropa, sebagian negara-negara di benua Afrika, Asia, dan Amerika serta di Australia dan Selandia Baru. Sebagian besar dari mereka bahkan menerapkannya sebagai directive ataupun mandatory policy. Definisi KLHS yang secara umum dirujuk oleh sebagian besar pengguna KLHS adalah sebagai berikut: "Suatu proses sistematis dan komprehensif untuk mengevaluasi dampak lingkungan, pertimbangan sosial dan ekonomi, serta prospek keberlanjutan dari usulan kebijakan, rencana, atau program pembangunan".

KLHS merupakan bagian dari keseluruhan Kajian Lingkungan Hidup (Environmental Assessments), yang dalam konteks proses pengambilan kebijakan pembangunan, dimanfaatkan mulai dari perumusan kebijakan, perencanaan, dan program. Tipikal kajiannya dapat berupa kajian terhadap aspek kebija- 
kan, aspek regional/ekoregion, aspek programatik, maupun aspek sektoral. Sementara itu pada tahap proyek, kajian lingkungan hidup dilaksanakan dengan menggunakan metode AMDAL.

Pengalaman implementasi berbagai instrumen pengelolaan lingkungan hidup, utamanya AMDAL, menunjukkan bahwa meskipun AMDAL sebagai salah satu instrumen pengelolaan lingkungan cukup efektif dalam memasukkan pertimbangan-pertimbangan lingkungan dalam rancang-bangun proyek-proyek individual, tapi secara konsep pembangunan menyeluruh, instrumen AMDAL belum memadai dalam memberikan jalan keluar terhadap dampak lingkungan kumulatif, dampak tidak langsung, dan dampak lingkungan sinergistik.

Pengalaman juga menunjukkan dalam proses pengambilan keputusan sering terjadi ketidakpastian, kesenjangan informasi dan kendala kognitif merupakan fenomena umum yang melatarbelakangi kegagalan pengambilan keputusan/kebijakan pembangunan berkelanjutan. Dalam konteks ini, ketidakpastian terbesar adalah dalam memprakirakan besarnya dampak Lingkungan Hidup yang timbul sebagai akibat implementasi Kebijakan, Rencana, Program (KRP). Pelaksana pembangunan atau pengambil kebijakan pembangunan yang berbeda mengacu pada atau memberikan interpretasi terhadap KRP secara berbeda pula sehingga menimbulkan persoalan dalam memprakirakan besarnya dampak.

Saat ini, pergeseran orientasi kebijakan pengelolaan lingkungan telah mengarah pada intervensi di tingkat makro dan pada tingkat hulu dari proses pengambilan keputusan pembangunan. Esensinya adalah bahwa kerjasama antar pelaku pembangunan dalam mewujudkan pembangunan berkelanjutan akan lebih efektif apabila lebih fokus pada upaya pencapaian pembangunan berkelanjutan pada tingkat makro/nasional daripada terbatas pada pendekatan di tingkat proyek di daerah.

Dalam konteks pergeseran strategi mewujudkan pembangunan berkelanjutan inilah peran KLHS menjadi penting. Implementasi KLHS juga diharapkan dapat men- gantisipasi terjadinya dampak lingkungan yang bersifat lintas batas (cross boundary environmental effects) dan lintas sektor. Penanganan dampak lintas wilayah dan lintas sektor ini diharapkan dapat menjadi jalan keluar atas permasalahan lingkungan hidup yang cenderung makin kompleks dengan dilaksanakannya, atau lebih tepatnya, distorsi pelaksanaan Undang-Undang Nomor 32 tahun 2004 jo Undang-Undang Nomor 12 Tahun 2008 tentang Pemerintahan Daerah.

Dengan demikian, KLHS seharusnya tidak diartikan sebagai instrumen pengelolaan lingkungan yang semata-mata ditujukan pada komponen-komponen Kebijakan, Rencana,Program,(KRP) tapi yang lebih penting adalah sebagai suatu cara untuk meyakinkan bahwa implikasi pelaksanaan KRP terhadap lingkungan hidup telah dijadikan pertimbangan dalam setiap tingkatan pengambilan keputusan, dan dengan demikian, keberlanjutan pembangunan dapat lebih terjamin Dengan kata lain, secara substansial, KLHS merupakan suatu upaya sistematis dan logis dalam memberikan landasan bagi terwujudnya pembangunan berkelanjutan melalui proses pengambilan keputusan yang bersifat holistik, berwawasan lingkungan, dan tidak hanya berdasarkan kepentingan keadaerahan semata (Hadi, 2002:1).

Saat ini sudah disusun peta dan deskripsi ekoregion DAS Daerah Aliran Sungai yang merupakan satu kesatuan ekoregion. Pada proses penetapan ekoregion tersebut, $\mathrm{KLH}$ bekerjasama dengan Badan Informasi Geospasial (sebelumnya Bakosurtanal) dan didukung oleh instansi pemerintah dan didukung oleh akademisi dari beberapa universitas dan LSM. Dalam proses memperkaya penyusunan ekoregion, KLH juga melibatkan berbagai narasumber lainnya dalam berbagai konsultasi publik. Untuk meningkatkan koordinasi antara pemangku kepentingan dalam penyediaan beberapa IGT yang dikoordinasikan oleh Badan Informasi Geospasial, dibentuk pula Kelompok Kerja Ekoregion yang diketuai oleh KLH.

Proses penetapan ekoregion tersebut dilakukan melalui beberapa tahapan, yaitu pemilihan parameter deliniator dan deskriptor, penyusunan hirarki ekoregion, pena- 
maan ekoregion, pemetaan, dan penyusunan deskripsi. Parameter deliniator adalah parameter yang digunakan untuk membatasi suatu ekoregion yang sifatnya statis. Sedangkan parameter deskriptor adalah parameter yang digunakan untuk menggambarkan karakteristik suatu ekoregion secara rinci yang bersifat dinamis.

Pasal 7 UU Nomor 32 tahun 2009 menetapkan bahwa terdapat 8 (delapan) pertimbangan untuk penetapan ekoregion, yaitu (a) karakteristik bentang alam; (b) daerah aliran sungai; (c) iklim; (d) flora dan fauna; (e) ekonomi, (f) kelembagaan masyarakat; (g) sosial budaya, dan (h) hasil inventarisasi lingkungan hidup Berdasarkan analisis dan kesepakatan para ahli terhadap 8 faktor tersebut, proses penetapan ekoregion darat menggunakan parameter deliniator bentang alam, yaitu morfologi (bentuk muka bumi) dan morfogenesa (asal usul pembentukan bumi). Sedangkan proses penetapan ekoregion laut menggunakan parameter deliniator morfologi pesisir dan laut, keanekaragaman hayati yang sifatnya statis, seperti karang keras, oseanografi, pasang surut, dan batas NKRI. Parameter lainnya yang disebutkan di atas, terutama yang sifatnya dinamis digunakan sebagai atribut untuk mendeskripsikan karakter ekoregion tersebut. Ekoregion dalam konsep ini ditekankan pada upaya sinergi, intergral dalam menjalankan fungsi koordinasi, dan seminasi informasi sehingga menjadi lancar terhadap penanganan isu-isu lingkungan.

Dengan ditentukan ekoregion akan menghubungan kebijakan antar daerah dan memasukan pertimbangan lingkungan dalam setiap kebijakan pembangunan serta melakukan pengawasan. Kebijakan itu berorintasi pada pemanfaatan sumber daya alam dan perubahan tata ruang yang dibuat dengan sesuai daya tampung dan daya dukung lingkungan.Pada akhirnya ekoregion dapat menetapkan kriteria-kreteria lingkungan hidup, pengembangan sitem informasi, pembangunan yang berkelanjutan dengan aspek lingkungan dan upaya-upaya dalam penangangan isu lingkungan hidup.

Berdasarkan uraian di atas, maka sudah saatnya dilakukan pendekatan ekoregion "ekoregion approach" produk-produk hukum di tingkat daerah dalam bentuk Perda dalam rangka pengelolaan DAS. Mengacu pada Teori Lawrence Friedman, bahwa bekerjanya hukum dipengaruhi tiga faktor, yaitu stuktur, substansi dan kultur.

Pertama, Struktur, dalam hal struktur sebenarnya sudah ada lembaga baik di tingkat pusat maupun daerah yang menangani pengelolaan DAS, yaitu Kementerian Kehutanan, Kementerian PU, Kementerian Lingkungan dan instansi terkait di tingkat pusat. Di tingkat daerah ada Dinas Kehutanan, Badan Lingkungan Hidup, Bappeda dan instansi terkait lainnya baik provinsi maupun kabupaten tapi lembaga-lembaga ini belum optimal dalam pengelolaan sumber daya air sungai. Belum optimalnya lembaga-lembaga ini mengelola sumber daya air sungai adalah kelembagaan ini bersifat ego sektoral. Sifat ini menghinggapi konstruksi stuktur organisasi perangkat daerah.

Birokrasi sektoral atau dalam istilah Nadler and Tushman (2008:112) adalah Organisasi Diferensiasi, yaitu suatu prinsip dalam organisasi yang menunjukkan bagaimana fungsi-fungsi satuan organisasi dirancang berbeda satu sama lain dalam melakukan transaksi dengan lingkungannya. Dengan demikian setiap unit atau satuan organisasi disusun/ dirancang harus menunjukkan perbedaan fungsi, aktivitas, wewenang dan tanggungjawabnya masing-masing. Selanjutnya Lawrence and Lorch menyatakan bahwa perbedaan dalam orientasi terhadap tujuan tertentu dari organisasi diferensiasi akan menyebabkan para anggota dari departemen yang berbeda mengembangkan pandangan-pandangan mereka sendiri tentang bagaimana cara mencapai kepentingan organisasi yang baik (Lawrence and Lorch, 2008:124).

Dari organisasi yang sektoral dalam legal structure di lembaga pemerintahan ini timbul gejala ego sektoral dalam pelaksanaannya, kaitannya dengan masalah pengelolaan sumber daya air sungai ini, maka keberlanjutan lingkungan hidup akan menjadi yang dikorbankan, karena tidak semua organisasi dalam lembaga pemerintahan memiliki kode komunikasi dalam keberlanjutan lingkungan hidup. Dalam perspektif teori sistem Niklas Luhmann ada sistem autopoie- 
tic, salah satu karakteristik sistem autopoietic adalah sistem yang tertutup. Ini berarti bahwa satu organisasi yang tertutup akan sangat membatasi komunikasinya dengan hal yang tidak ada kaitan langsung antara sistem dengan lingkungannya. Sistem organisasi seperti ini dapat eksis karena pembatasan komunikasi ini (Luhman dalam Ritzer and Goodman, 2008:33).

Sistem autopoietic dalam masyarakat modern diterjemahkan ke dalam proses diferensiasi. Diferensiasi di dalam sistem adalah cara penanganan perubahan dalam lingkungannya. Masing-masing sistem harus menjaga batas-batasnya dalam hubungannya dengan lingkungannya. Jika tidak ia akan dikuasai oleh kompleksitas lingkungannya, ambruk dan berhenti eksis. Maka untuk berkomunikasi dengan sistemnya yang lebih luas sebuah organisasi memerlukan sebuah kode, ini dipakai untuk membatasi jenis komunikasi yang diperbolehkan. Setiap komunikasi yang tidak menggunakan kode itu bukan komunikasi yang masuk dalam sebuah sistem terkait dalam organisasi.

Kode lingkungan hidup ada di Badan Lingkungan Hidup yang ada di satu daerah, sementara di Badan perizinan Terpadu, Dinas Tata Banguna dan Pemukiman, PLN, Bina Marga dan Pengairan dan lembaga-lembaga yang lain di daerah yang lain, kode lingkungan nya berbeda satu dengan yang lain. Masalahnya adalah, lingkungan hidup atau keberlanjutan lingkungan hidup tidak mungkin ditangani secara sektoral dengan kode yang berbeda beda kualitas dan kuantitasnya. Untuk itu diperlukan suatu organisasi dengan koordinasi, yang komunikasi antar organisasinya memiliki kode sentral keberlanjutan lingkungan hidup. Perlu dibangun kedepannya adalah lembaga-lembaga antar daerah berdasarkan ekoregion yang menangani pengelolaan sumber daya air sungai. Lembaga ini tidak "berpihak" pada daerah manapun, tetapi fokus dalam pengelolaan sumber daya air sungai dari hulu sampai hilir.

Kedua, Substansi. Pada sisi substansi, di tingkat pusat sudah ada UU Sumber Daya Air, UU Kehutanan, UU Perlindungan dan Pengelolaan Lingkungan Hidup, bahkan saat ini sudah ada PP Nomor 37 Tahun 2012 tentang Pengelolaan Daerah Aliran Sungai. Kelemahannya adalah belum ada Perda yang mengatur tentang pengelolaan sumber daya air sungai dan juga belum ada aturan tentang kerja sama antar daerah berdasarkan ekoregion dari hulu sampai hilir dalam pengeIolaan DAS ini. Selain hal tersebut Peraturan Daerah cenderung bersifat anthroposentris yang menempatkan manusia sebagai pusat dari sistem. Sehingga bernilai atau tidaknya sumber daya alam selalu diukur dari sudut pandang kepentingan manusia.

Kecenderungan peraturan yang bersifat anthroposentris telah menjadi penyebab paling mendasar terjadinya berbagai problem ekologis yang melanda bumi ini, yang dampaknya akan menghantam balik kebahagiaan kehidupan manusia. Berdasarkan hal tersebut saat ini perkembangan dunia dalam paradigma berpikir mulai berubah kearah nilainilai deep ecology. Paradigma berfikir baru dari Capra (Capra 2001; Capra, 2007) ini, tertuang dalam bukunya The turning point. Capra mulai meninggalkan pradigma fisika dan mistis pada paradigma biologis dan ekologis.

Dalam buku ini Capra kemudian menyimpulkan penemuannya dalam bidang biologi tersebut yang akhirnya mengantarkannya pada paradigma baru yang disebutnya ekologis dan sistemik. Pendapat ini Capra temukan ketika dia mencoba menjelaskan bahwa sistem yang ada dalam organisme adalah saling bergantung dan dalam prosesnya kesaling tergantungan itu mempunyai kekuatan untuk memperbaiki diri ketika masing-masing ada kerusakan, kemampuan untuk menyembuhkan ini disebutkan oleh Capra dengan swa-organisasi yang kemudian diidentifikasi sebagai seauatu yang lain dan tidak lain adalah Tuhan.

Satjipto Raharjo dalam pemikiran Hukum Progresif mencoba menyoroti kondisi di atas ke dalam situasi ilmu-ilmu sosial, termasuk Ilmu Hukum, meski tidak sedramatis dalam ilmu fisika, tetapi pada dasarnya terjadi perubahan yang fenomenal mengenai hukum yang dirumuskannya dengan kalimat "dari yang sederhana menjadi rumit" dan "dari yang terkotak-kotak menjadi kesatuan" Inilah yang disebutnya sebagai pandangan holistik dalam ilmu (Hukum). Pandangan 
holistik ini memberikan kesadaran visioner bahwa sesuatu dalam tatanan tertentu memiliki bagian yang saling berkaitan baik dengan bagian lainnya atau dengan keseluruhannya (Rahardjo, 2004:18).

Sebenarnya pemikiran yang bersifat holistik ini secara ideal sudah terdapat dalam pasal 2 Undang Undang Nomor 7 Tahun 2004 tentang Sumber Daya Air. Pasal tersebut telah menegaskan bahwa sumber daya air dikelola berdasarkan asas kelestarian, keseimbangan, kemanfaatan umum, keterpaduan dan keserasian, keadilan, kemandirian, serta transparansi dan akuntabilitas. Pengertian dari asas-asas tersebut dapat dijelaskan sebagai berikut:

1. Asas kelestarian mengandung pengertian bahwa pendayagunaan sumber daya air diselenggarakan dengan menjaga kelestarian fungsi sumber daya air secara berkelanjutan.

2. Asas keseimbangan mengandung pengertian bahwa ada keseimbangan antara fungsi sosial, fungsi lingkungan hidup, dan fungsi ekonomi.

3. Asas kemanfaatan umum mengandung pengertian bahwa pengelolaan sumber daya air dilaksanakan untuk memberikan manfaat yang sebesar-besarnya bagi kepentingan umum secara efektif dan efisien.

4. Asas keterpaduan dan keserasian mengandung pengertian bahwa pengelolaan sumber daya air dilakukan secara terpadu dalam mewujudkan keserasian untuk berbagai kepentingan dengan memperhatikan sifat air yang dinamis.

5. Asas keadilan mengandung arti bahwa pengelolaan sumber daya air dilakukan secara merata keseluruh lapisan masyarakat di wilayah tanah air sehingga setiap warga negara berhak memperoleh kesempatan yang sama untuk berperan dan menikmati hasilnya secara nyata.

6. Asas kemandirian berarti bahwa pengelolaan sumber daya air dilakukan dengan memperhatikan kemampuan dan keunggulan sumber daya setempat.

7. Asas transparansi dan akuntabilitas mengandung pengertian bahwa pen- gelolaan sumber cdaya air dilakukan secara terbuka dan dapat dipertanggungjawabkan.

Lebih jauh mengenai asas keterpaduan yang kemudian diterapkan dalam Daerah Aliran Sungai (DAS) sesungguhnya mengandung arti keterpaduan secara horisontal dan vertikal. Secara horisontal, harus ada keterpaduan perencanaan antar sektor, misalnya pertanian dan konservasi yang berada di DAS hulu, sektor perikanan (tangkap maupun budidaya), sektor pariwisata, perhubungan laut, serta pengembangan kota. Sedangkan keterpaduan perencanaan secara vertikal meliputi keterpaduan kebijakan perencanaan dan operasional mulai dari tingkat desa, kecamatan, kabupaten/kota, provinsi, sampai nasional. Lebih jauh, Pratikto (2006:59) menjelaskan bahwa konsep pengelolaan kawasan pesisir terpadu seyogyanya menggunakan pendekatan batas batas ekologis, salah satunya dengan menempatkan DAS sebagai basis perencanaan, sehingga dampak dari kegiatan pertanian, industri maupun pembangunan perkotaan di DAS perlu diperhatikan.

Pendekatan Ekoregion merupakan koreksi atas kebijakan pengelolaan daerah aliran sungai yang masih dilakukan dalam batasan wilayah administratif. Pendekatan ekoregion merupakan aplikasi dari pandangan holistik dalam tatanan hukum. Memberikan kesadaran visioner bahwa sesuatu dalam tatanan tertentu memiliki bagian yang saling berkaitan baik dengan bagian lainnya atau dengan keseluruhannya. Berdasarkan teori-teori di atas, kedepannya perlu dibangun peraturan daerah tentang pengelolaan dan perlindungan DAS dalam paradigma pembangunan yang berwawasan lingkungan, oleh sebab itu sudah saatnya pengelolaan DAS dilakukan dengan pendekatan ekoregion sejalan dengan instrumen lingkungan hidup yang terdiri dari RPPLH, KLHS, Baku Mutu Lingkungan Hidup, Baku Mutu Kerusakan dan AMDAL.

Ketiga, Kultur. Dalam pengelolaan sumber daya air sungai, faktor budaya hukum ini ini juga berperan sangat penting. Mengenai budaya hukum ini, Friedman mengemukakan bahwa budaya hukum terdiri dari internal legal culture yaitu budaya hukum dari pemerintahan. Perlu dibangun Peme- 
rintahan dengan birokrasi yang bersifat holistik dalam pengelolaan sumber daya alam (khususnya sumber daya air sungai) dengan budaya cara pandang yang bersifat holistik ini, pengelolaan tidak lagi dipandang sebagai kepentingan sektoral. Implementasi dari budaya cara pandang yang bersifat holistik akan memudahkan pendekatan ekoregion dalam pengelolaan sumber daya air sungai. Dalam budaya pemerintahan yang bersifat holistik ini juga akan memandang pembangunan dari berbagai segi, bukan hanya dititik beratkan dari segi ekonomi saja, tetapi juga dari segi sosial, budaya masyarakat dan pembangunan kelestarian lingkungan.

Budaya yang lainnya adalah Eksternal legal culture, adalah budaya hukum masyarakat, terutama dalam hal budaya sadar lingkungan dan mengelola sumber daya air sungai secara lestari dan berkelanjutan. Budaya sadar lingkungan akan lebih memudahkan implementasi pendekatan ekoregion dalam pengelolaan sumber daya air sungai. Dalam rangka pelestarian tata nilai sosial budaya agar ditaati oleh masyarakat diperlukan norma sosial yang disebut hukum. Sebagai norma sosial, hukum tidak dapat dilepaskan dari nilai-nilai sosial budaya masyarakat. $\mathrm{Ni}-$ lai merupakan segala sesuatu yang dianggap baik dan diharapkan oleh masyarakat, oleh karena itu nilai sosial budaya berarti penghargaan yang diberikan masyarakat kepada segala sesuatu yang mempunyai kegunaan/ manfaat bagi perkembangan kebudayaan masyarakat.

Dalam kaitannya dengan pembuatan hukum, maka hukum yang ideal dan baik adalah hukum yang mengandung nilai-nilai sosial budaya yang berlaku dalam masyarakat. Hal ini bertujuan agar tercipta kesesuaian dan keharmonisan antara hukum yang dibuat dengan nilai-nilai yang berkembang di dalam kehidupan masyarakat. Namun, idealisme tersebut tidak mudah dilaksanakan dalam pembuatan hukum tertulis (hukum negara) yang dikenal dengan state law . Secara sosiologis, hukum sumber daya air sungai yang berlaku di Indonesia, selain hukum tertulis (peraturan perundang-undangan) juga berlaku hukum tidak tertulis (Hukum Adat) serta Hukum Agama (Sulastriyono, 2008:75). Kedua macam hukum tersebut dapat dikategorikan sebagai hukum yang tidak terorganisasi dan bersifat luwes. Hal ini karena proses pembuatan dan penegakan hukumnya tidak dileng-kapi dengan organisasi/lembaga penegak hukum seperti polisi, jaksa dan hakim seperti yang dikenal di negara barat. Kenyataan inilah yang sering dipandang oleh ahli hukum barat sebagai kelemahan Kelemahan lainnya adalah bahwa aturan dalam Hukum Adat dan Hukum Agama sering tidak rasional. Hukum Adat dan Hukum Agama dikatakan bersifat luwes karena hukum tersebut merupakan hukum yang senantiasa hidup, tumbuh dan berkembang serta berlaku di masyarakat sebagai norma/pedoman hidup manusia yang mengandung nilai-nilai sosial budaya masyarakat sehingga mudah menyesuaikan diri dengan perkembangan masyarakat.

Peran serta masyarakat dengan budaya hukumnya, berperan signifikan dalam pengelolaan sumber daya alam dan lingkungan yang adil dan berkelanjutan. Keterlibatan masyarakat juga membuat nilai-nilai sosial budaya, ekonomi dan ekologi lokal yang menjadi elemen penting pelestarian alam juga sumber daya air sungai berjalan beriringan dengan program kebijakan pemerintah. Tanpa budaya hukum pelrestarian sumber daya air sungai dari masyarakat, program sebaik apapun dari pemerintah akan sulit dijalankan.

Tak bisa dipungkiri lagi bahwa masyarakat memiliki kearifan budaya yang nyata untuk menjaga kelestarian sumber daya air sungai secara khusus maupun lingkungan secara umum seperti melakukan pelestarian mata air dengan ritual adat maupun aksi nyata dengan penanaman pohon di sekitar mata air," Kesadaran masyarakat untuk menjaga wilayah mereka lewat hukum adat, sudah banyak memberikan manfaat bagi masyarakat adat secara langsung di berbagai wilayah di tanah air. Aktivitas dari budaya ini, memberikan hasil yang nyata bagi pelestarian sumber daya air sungai dan masyarakat setempat dengan cara yang berkelanjutan. 


\section{Simpulan}

Dari uraian di atas dapat disimpulkan bahwa dari struktur hukum lembaga-lembaga terkait dalam pengelolaan sumber daya air di tingkat daerah sudah saatnya menggunakan ekoregion approach dalam segala aktifitas birokrasinya. Kerjasama antar daerah berbasis ekoregion akan memudahkan pengelolaan secara terpadu, terkoordinasi dan terorganisir dengan baik. Secara substansi hukum, Perda Pengelolaan sumber daya air sungai dengan ekoregion approach sudah saatnya dibentuk dan urgen dalam rangka penguatan fungsi lingkungan hidup dan mewujudkan pembangunan yang berwawasan lingkungan. Demikian juga perlu dibangun kultur hukum yang bersifat holistik, baik dari kultur pemerintahan (internal legal culture) maupun dari masyarakat (eksternal legal culture). Kultur pemerintahan yang holistik membiasakan kerjasama terpadu dari berbagai pihak dan Kultur hukum dari masyarakat sangat membantu pelestarian sumber daya air sungai dari hilir sampai hulu.

Mengingat permasalahan yang kompleks serta payung hukum pengelolaan sumber daya air sungai di tingkat daerah belum tersedia, khususnya Perda khusus Pengelolaan sumber daya air sungai. Dalam rangka pengelolaan yang terpadu maka perlu diterbitkan Perda-Perda Pengelolaan sumber daya air sungai dalam rangka penguatan fungsi lingkungan hidup dan terwujudnya pembangunan yang berwawasan lingkungan. Pembentukan peraturan dengan pendekatan ekoregion, ini masuk hal baru, perlu ada sosialisasi ditingkat kabupaten dan kota, satu hal lagi tidak ada izin usaha yang diperoleh tanpa ijin lingkungan yang berbasis ekoregion. Ini penting untuk membuat semua orang di negeri ini baik pemerintah, swasta, dan masyarakat memandang penting lingkungan hidup. Sehingga kita bangga pada generasi kelak dengan mewariskan lingkungan yang bersih dan sehat.

\section{Daftar Pustaka}

Akib, Muhamad. 2011. Penegakan Hukum Lingkungan Dalam Perspektif Holistik Ekologis. Bandar Lampung: Penerbit Universitas Lampung.

Asshiddiqie, Jimly. 2010. Green Constitution Nuansa Hijau Undang Undang Dasar Negara Republik Indonesia Tahun 1945. Jakarta: Rajawali Pers.

Budiman Arif, "Reformasi Hukum dan Kebijakan Sumber Daya Air Menuju Pengaktualisasian Pengelolaan Sumber Daya Air yang Berkelanjutan dan Berwawasan Lingkungan serta Berbasis Kerakyatan", (Makalah tidak diterbitkan).

C. Asdak. Daerah Aliran Sungai Sebagai Satuan Monitoring dan Evaluasi Lingkungan: Air Sebagai Indikator Sentral. Seminar Sehari PERSAKI: DAS Sebagai Satuan Perencanaan Terpadu Dalam Pengelolaan Sumberdaya Air. Jakarta, 21 Desember 1999.

Capra Fritjop, 2001. The Web of Life, A New Synthesis of Mind and Mather (Edisi Indonesia: JaringJaring Kehidupan, Visi baru Epistemologi dan Kehidupan, terjemahan Saut Pasaribu) Yogayakarta: Fajar Pustaka Baru.

Capra Fritjop, 2007. The Turning Point: Titik Balik Perdaban Sains Masyarakat dan Kebangkitan Kebudayaan. Jejak. Yogyakarta. Cet 1.

E.Effendi E. 2008. Kajian Model Pengelolaan Daerah Aliran Sungai (DAS) Terpadu. Jakarta: Direktorat Kehutanan dan Konservasi Sumberdaya Air.

Friedman Lawrence Friedman, 1975. The Legal System: A Social Science Perspective. ( New York: Russell Sage Foundation.

Giddens Anthony and Jonathan Turner, 2008. Social Theory Today (Panduan Sistemik Tradisi danTrend Terdepan Teori Social). Yogyakarta: Pustaka Pelajar.

Hadi P Sudharto, 2002. Dimensi Hukum Pembangunan Berkelanjutan.. Semarang: Badan Penerbit Universitas Diponegoro. Cetakan ke I.

Handayani I gusti Ayu Ketut Rachmi dan Lientje Anna Marpaung, "Konservasi Kawasan DAS Solo Hulu dalam rangka Sustainable Development (Perspektif HAN)". Jurnal Bestuur Edisi 02 Februari -Mei 2013.

Handayani I gusti Ayu Ketut Rachmi dan Lientje Anna Marpaung, "Urgensi Perda Pengelola DAS Bengawan Solo dalam Rangka Penguatan Fungsi Lingkungan Hidup dan Good Governance". Jurnal Hukum IUS QUIA IUSTUM. No. 2 Vol.20. April 2013 
Irianto (a), Sulistyowati, "Memperkenalkan Studi Sosio legal dan Implikasi Metodologisnya dalam Metode Penelitian Hukum, Konstelasi dan Refleksi". Jakarta: Jurnal JHMP-FHUI, 2009.

Irianto (b), Sulistyowati, 2009. "Meratas Jalan Keadilan Bagi Kaum Terpinggirkan dan Perempuan (Suatu Tinjauan Sosiolegal)", Pidato pada Upacara Pengukuhan Guru Besar Tetap dalam IImu Antropologi Hukum pada Fakultas Hukum Universitas Indonesia, Jakarta.

Lorch and Lawrence dalam Miftah Thoha, 2008. Birokrasi Pemerintah Indonesia di Era Reformasi. Kencana Prenada Media Group. Jakarta.

Luhman Nikhlas dalam George Ritzer \& Douglas J.Goodman, 2008. Teori Sosiologi Modern. Kencana Prenada Media Group. Jakarta.

Rahardjo, Satjipto, 2004. Ilmu Hukum; Pencarian, Pembebasan dan Pencerahan, Muhamadiyah Press University.

Rahardjo, Satjipto, 2009. Hukum Progresif Sebuah Sintesa Hukum Indonesia, Yogyakarta: Genta Publishing.

Raharja Sam'un Jaja, “Paradigma Governance dalam Penerapan Manajemen Kebijakan Sektor Publik pada Pengelolaan Sungai", Jurnal IImu Administrasi dan Organisasi, Bisnis \& Birokrasi, Mei-Agustus 2009, Volume 16, Nomor 2ISSN 0854-384.
Sulastriyono, "Pembangunan Hukum Sumber Daya Air Sungai yang Berbasis Kearifan Lokal: Peluang dan Tantangannya". Jurnal Mimbar Hukum Vol.20 No.3 Oktober Tahun 2008.

Sunarti, 2008. Pengelolaan DAS berbasis Bioregion (Suatu Alternatif Menuju Pengelolaan Berkelanjutan). Jakarta: Direktorat Jenderal Rehabilitasi Lahan dan Perhutanan Sosial, Departemen Kehutanan

Tushman and Nadler dalam YT. Keban . Enam Dimensi Strategis Administrasi Publik, Konsep, Teori dan Isu, Yogyakarta: Gava Meia, 2008

Wignjosoebroto, Soetandyo, "Penelitian Hukum dan Hakikatnya sebagai Penelitian Ilmiah, Metode Penelitian Hukum, Konstelasi dan Refleksi". Jakarta: Jurnal JHMP-FHUI, 2009

\section{Peraturan Perundang-undangan}

Undang-Undang Nomor 32 tahun 2004 jo Undang Undang Nomor 12 Tahun 2008 tentang Pemerintahan Daerah

Undang-Undang Nomor 32 tahun 2009 tentang Perlindungan dan Pengelolaan Lingkungan Hidup

Undang -Undang Nomor 7 tahun 2004 tentang Sumber Daya Air

PP Nomor 37 Tahun 2012 tentang Pengelolaan Daerah Aliran Sungai 